and led to significant reduction of inflammatory MRI lesions in the spine and the Sacroiliac Joints. The safety profile of secukinumab through Wk 52 was consistent with previous reports. ${ }^{3-4}$

References:

[1] Mclnnes IB, et al. Lancet. 2015;386(9999):1137-46.

[2] Baraliakos X, et al. Arthritis Rheumatol. 2019;71 (suppl 10).

[3] Langley RG, et al. N Engl J Med. 2014;371:326-38.

[4] Sieper J, et al. Ann Rheum Dis. 2016;0:1-8.

Acknowledgments: The study was sponsored by Novartis Pharma AG, Basel, Switzerland.

Disclosure of Interests: Xenofon Baraliakos Grant/research support from: Grant/ research support from: AbbVie, BMS, Celgene, Chugai, Merck, Novartis, Pfizer, UCB and Werfen, Consultant of: AbbVie, BMS, Celgene, Chugai, Merck, Novartis, Pfizer, UCB and Werfen, Speakers bureau: AbbVie, BMS, Celgene, Chugai, Merck, Novartis, Pfizer, UCB and Werfen, Laure Gossec Grant/research support from: Lilly, Mylan, Pfizer, Sandoz, Consultant of: AbbVie, Amgen, Biogen, Celgene, Janssen, Lilly, Novartis, Pfizer, Sandoz, Sanofi-Aventis, UCB, Effie Pournara Shareholder of: Novartis, Employee of: Novartis, Sławomir Jeka Grant/ research support from: AbbVie, Pfizer, Roche, Novartis, MSD, Sandoz, Eli Lilly, Egis, UCB, Celgene, Speakers bureau: AbbVie, Pfizer, Roche, Novartis, MSD, Sandoz, Eli Lilly, Egis, UCB, Celgene, Ricardo Blanco Grant/research support from: AbbVie, MSD, Roche, Consultant of: Abbvie, Eli Lilly, Pfizer, Roche, Bristol-Myers, Janssen, UCB Pharma and MSD, Speakers bureau: Abbvie, Eli Lilly, Pfizer, Roche, Bristol-Myers, Janssen, UCB Pharma. MSD, Salvatore D'Angelo Consultant of: AbbVie, Biogen, BMS, Celgene, Eli Lilly, MSD, Novartis, and UCB, Speakers bureau: AbbVie, BMS, Celgene, Eli Lilly, Novartis, Pfizer, and Sanofi, Georg Schett Speakers bureau: AbbVie, BMS, Celgene, Janssen, Eli Lilly, Novartis, Roche and UCB, Barbara Schulz Employee of: Novartis, Michael Rissler Shareholder of: Novartis, Employee of: Novartis, Kriti Nagar Employee of: Novartis, Chiara Perella Shareholder of: Novartis, Employee of: Novartis, Laura C Coates: None declared

DOI: 10.1136/annrheumdis-2020-eular.638

\section{OP0054 EFFICACY OF GUSELKUMAB, A MONOCLONAL ANTIBODY THAT SPECIFICALLY BINDS TO THE P19- SUBUNIT OF IL-23, ON ENDPOINTS RELATED TO AXIAL INVOLVEMENT IN PATIENTS WITH ACTIVE PSA WITH IMAGING-CONFIRMED SACROILIITIS: WEEK- 24 RESULTS FROM TWO PHASE 3, RANDOMIZED, DOUBLE-BLIND, PLACEBO-CONTROLLED STUDIES}

$\underline{\text { P. Helliwell }}{ }^{1}$, D. D. Gladman ${ }^{2}$, D. Poddubnyy ${ }^{3,4}$, P. J. Mease ${ }^{5}$, X. Baraliakos ${ }^{6}$,

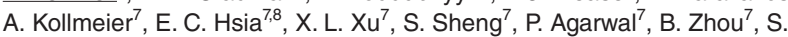
D. Chakravarty ${ }^{9,10}$, M. Shawi ${ }^{11}$, C. Karyekar ${ }^{11}$, A. Deodhar ${ }^{12}$, D. Van der Heijde ${ }^{13}$. ${ }^{1}$ University of Leeds, Leeds, United Kingdom; ${ }^{2}$ Toronto Western Hospital and University of Toronto, Ontario, Canada; ${ }^{3}$ Charite Universitatsmedizin Berlin Campus Benjamin Franklin, Berlin, Germany; ${ }^{4}$ German Rheumatism Research Centre, Berlin, Germany; ${ }^{5}$ Swedish Medical Center/Providence St. Joseph Health and University of Washington, Seattle, United States of America; ${ }^{6}$ Rheumazentrum Ruhrgebiet, Ruhr-University Bochum, Herne, Germany; ${ }^{7}$ Janssen Research \& Development, LLC, Spring House, United States of America; ${ }^{8} \mathrm{U}$ Penn Med Ctr, Philadelphia, United States of America; ${ }^{9} \mathrm{Janssen}$ Scientific Affairs, LLC, Horsham, United States of America; ${ }^{10}$ Drexel University College of Medicine, Philadelphia, United States of America; ${ }^{11}$ Janssen Global Services, LLC, Horsham, United States of America; ${ }^{12}$ Oregon Health \& Science University, Portland, United States of America; ${ }^{13}$ Leiden University Medical Center, Leiden, Netherlands

Background: Guselkumab (GUS), an interleukin-23 inhibitor, was efficacious in reducing signs and symptoms of active psoriatic arthritis (PsA) in patients (pts) in two phase 3 trials (DISCOVER-1 and DISCOVER-2).

Objectives: To evaluate the efficacy of GUS in PsA pts with imaging-confirmed axial involvement consistent with sacroiliitis in DISCOVER-1\&2.

Methods: In DISCOVER-1, 381 pts with active PsA ( $\geq 3$ swollen joints, $\geq 3$ tender joints; C-reactive protein $\geq 0.3 \mathrm{mg} / \mathrm{dL}$ despite standard therapies) and in DISCOVER-2, 739 pts with active PsA ( $\geq 5$ swollen joints, $\geq 5$ tender joints, $\mathrm{CRP} \geq 0.6 \mathrm{mg} / \mathrm{dL}$ despite standard therapies) were randomized 1:1:1 to GUS 100mg Q4W, GUS 100mg Q8W (Wk0, Wk4, then Q8W), or PBO. This analysis included pts with sacroiliitis at baseline who had either documented imaging confirmation of sacroiliitis in the past or pelvic X-ray confirmation of sacroiliitis at screening (pooled data from DISCOVER-1\&2) based on investigators' judgment of presence/absence of sacroiliitis. Efficacy was assessed by BASDAI score, BASDAI50, modified BASDAI (mBASDAl; excludes Q\#3), spinal pain (BASDAI Q\#2), ASDAS-CRP score, and ASDAS responses of inactive disease $(<1.3$ ), major improvement (decrease $\geq 2.0$ ), and clinically important improvement (decrease $\geq 1.1$ ). Pts with missing data at wk24 were classified as nonresponders.
Results: 312 pts presented with axial involvement (PBO, $n=118$; GUS q8w, $n=$ 91; GUS q4w, $n=103$ ). The LS mean changes from baseline to wk24 in BASDAI, spinal pain, mBASDAI, and ASDAS-CRP were greater in the two GUS groups vs PBO (Table). Greater proportions of GUS-treated pts achieved BASDAI50 (Table) and ASDAS responses of inactive disease, major improvement, and clinically important improvement (Figure) at wk24 vs PBO.

Conclusion: GUS improved axial symptoms over 24 weeks in active PsA patients with imaging-confirmed sacroiliitis.

Table. Efficacy of GUS in PsA patients with axial involvement at week 24.

\begin{tabular}{|c|c|c|c|}
\hline & $\begin{array}{c}\text { PBO } \\
(n=118)\end{array}$ & $\begin{array}{l}\text { GUS } 100 \mathrm{mg} \\
\text { every } 8 \text { weeks } \\
\quad(n=91)\end{array}$ & $\begin{array}{c}\text { GUS100 mg } \\
\text { every } 4 \text { weeks } \\
\quad(n=103)\end{array}$ \\
\hline LS Mean change in BASDAI & -1.35 & $-2.67^{\star}$ & $-2.68^{*}$ \\
\hline LS Mean change in spinal pain ${ }^{b}$ & -1.30 & $-2.73^{\star}$ & $-2.48^{\star}$ \\
\hline BASDAI $50^{\circ}, \%$ & $21 / 110(19.1 \%)$ & $34 / 84(40.5 \%)^{\star \star}$ & $36 / 95(37.9 \%)^{\star \star}$ \\
\hline LS Mean change in modified & -1.13 & $-2.16^{\star}$ & $-2.18^{\star}$ \\
\hline LS Mean change in ASDAS-CRP & -0.71 & $-1.43^{\star}$ & $-1.46^{\star}$ \\
\hline
\end{tabular}

${ }^{\text {aPts }}$ with axial involvement consistent with sacroiliitis at baseline and either a history of imaging confirmation or pelvic X-ray at screening (pooled data from DISCOVER-1 \& 2)

${ }^{\mathrm{b}}$ Question 2 of the BASDAI.

${ }^{\mathrm{c}} \mathrm{Pts}$ with BASDAI $>0$ at baseline.

${ }^{d}$ Excludes question 3 of the BASDAI.

Unadjusted $p$-values as noted: ${ }^{*} p<0.001,{ }^{* *} p<0.01$

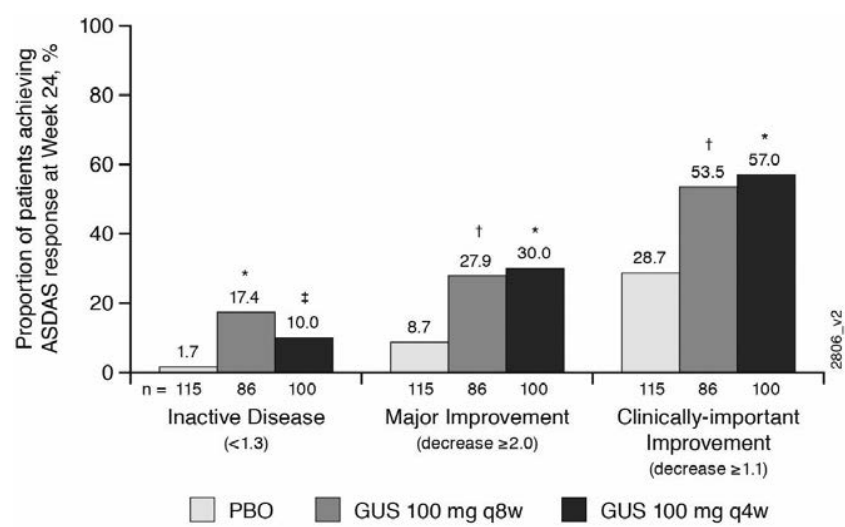

$\cdot p<0.001 ; \uparrow<0.01 ; \neq p<0.05$

\section{Acknowledgments: None}

Disclosure of Interests: Philip Helliwell: None declared, Dafna D Gladman Grant/research support from: AbbVie, Amgen Inc., BMS, Celgene Corporation, Janssen, Novartis, Pfizer, UCB - grant/research support, Consultant of: AbbVie, Amgen Inc., BMS, Celgene Corporation, Janssen, Novartis, Pfizer, UCB - consultant, Denis Poddubnyy Grant/research support from: AbbVie, MSD, Novartis, and Pfizer, Consultant of: AbbVie, Bristol-Myers Squibb, Eli Lilly, MSD, Novartis Pfizer, Roche, UCB, Speakers bureau: AbbVie, Bristol-Myers Squibb, Eli Lilly, MSD, Novartis, Pfizer, Roche, UCB, Philip J Mease Grant/research support from: AbbVie, Amgen, Bristol-Myers Squibb, Janssen, Eli Lilly, Novartis, Pfizer, Sun Pharma, UCB Pharma, Consultant of: AbbVie, Amgen, Bristol-Myers Squibb, Celgene, Janssen, Eli Lilly, Galapagos, Gilead, Novartis, Pfizer, Sun Pharma UCB Pharma, Speakers bureau: AbbVie, Amgen, Bristol-Myers Squibb, Celgene Genentech, Janssen, Novartis, Pfizer, UCB Pharma, Xenofon Baraliakos Grant/ research support from: Grant/research support from: AbbVie, BMS, Celgene, Chugai, Merck, Novartis, Pfizer, UCB and Werfen, Consultant of: AbbVie, BMS, Celgene, Chugai, Merck, Novartis, Pfizer, UCB and Werfen, Speakers bureau: AbbVie, BMS, Celgene, Chugai, Merck, Novartis, Pfizer, UCB and Werfen, Alexa Kollmeier Shareholder of: Johnson \& Johnson, Employee of: Janssen Research \& Development, LLC, Elizabeth C Hsia Shareholder of: Johnson \& Johnson, Employee of: Janssen Research \& Development, LLC, Xie L Xu Shareholder of: Johnson \& Johnson, Employee of: Janssen Research \& Development, LLC Shihong Sheng Shareholder of: Johnson \& Johnson, Employee of: Janssen Research \& Development, LLC, Prasheen Agarwal Shareholder of: Johnson \& Johnson, Employee of: Janssen Research \& Development, LLC, Bei Zhou Shareholder of: Johnson \& Johnson, Employee of: Janssen Research \& Development LLC, Soumya D Chakravarty Shareholder of: Johnson \& Johnson, Employee of: Janssen Scientific Affairs, LLC, May Shawi Shareholder of: Johnson \& Johnson, Employee of: Janssen Research \& Development, LLC, Chetan Karyekar Shareholder of: Johnson \& Johnson, Consultant of: Janssen, Employee of: Janssen Global Services, LLC. Previously, Novartis, Bristol-Myers Squibb, and Abbott 
Labs., Atul Deodhar Grant/research support from: AbbVie, Eli Lilly, GSK, Novartis, Pfizer, UCB, Consultant of: AbbVie, Amgen, Boehringer Ingelheim, Bristol Myer Squibb (BMS), Eli Lilly, GSK, Janssen, Novartis, Pfizer, UCB, Speakers bureau: AbbVie, Amgen, Boehringer Ingelheim, Bristol Myer Squibb (BMS), Eli Lilly, GSK, Janssen, Novartis, Pfizer, UCB, Désirée van der Heijde Consultant of: AbbVie, Amgen, Astellas, AstraZeneca, BMS, Boehringer Ingelheim, Celgene, Cyxone, Daiichi, Eisai, Eli-Lilly, Galapagos, Gilead Sciences, Inc., Glaxo-SmithKline, Janssen, Merck, Novartis, Pfizer, Regeneron, Roche, Sanofi, Takeda, UCB Pharma; Director of Imaging Rheumatology BV

DOI: 10.1136/annrheumdis-2020-eular.474

\section{OP0055 MINIMAL RADIOGRAPHIC DAMAGE OF SACROILIAC JOINTS DETECTED IN PSORIATIC ARTHRITIS PATIENTS}

M. De Hooge ${ }^{1,2}$, A. Ishchenko ${ }^{3}$, S. Steinfeld ${ }^{4}$, A. Nzeusseu Toukap ${ }^{5}$,

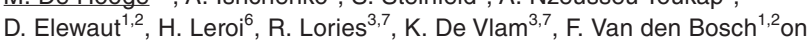
behalf of the BEPAS Study Group. ${ }^{1}$ Ghent University Hospital, Ghent, Belgium; ${ }^{2}$ VIB Ghent University, Ghent, Belgium; ${ }^{3}$ University Hospitals Leuven, Leuven, Belgium; ${ }^{4}$ Clinique St Jean, Brussels, Belgium; ${ }^{5}$ UCLouvain, Brussels, Belgium; ${ }^{6}$ MSD Belgium, Brussels, Belgium; ${ }^{7}$ KU Leuven, Leuven, Belgium

Background: Psoriatic arthritis (PsA) is an inflammatory joint disease that is traditionally included in the Spondyloarthritis (SpA) spectrum. Prevalence and impact of axial involvement in PsA remains understudied but increasingly affects treatment decisions.

Objectives: The first step, in this multi-purpose radiographic study, is to report on baseline radiographic damage of the sacroiliac joints (SIJ) in PsA patients from a prospective multicentre cohort study in private and academic rheumatology practices.

Methods: Data from the Belgian Epidemiological Psoriatic Arthritis Study (BEPAS), a prospective multicentre cohort involving 17 Belgian rheumatology practices. Recruitment was from December 2012 until July 2014. Patients were included in the study when the local rheumatologist could diagnose an existing or new PsA and when patients fulfilled the Classification criteria for Psoriatic Arthritis (CASPAR). Radiographs of the SIJ were obtained at baseline and after 2 years. Two calibrated readers assessed radiographic damage by grading the SIJ according to the modified New York (mNY) criteria. When assessing the images, readers were blinded for clinical data and information from other obtained images (radiographs of the hands, feet and spine). Individual scores as well as consensus scores are described.

Results: In total 461 patients where included in BEPAS. Mean age was $52.79 \pm 12.29$ years and $43.0 \%(n=198)$ were female; average disease duration was $8.5 \pm 9.3 \mathrm{yrs}$ and approximately $34 \%$ of the patients report inflammatory axial pain. From 338 patients SIJ radiographs were obtained. At baseline, the vast majority of patients did not fulfil the $\mathrm{mNY}$ criteria $(n=325,96.2 \%)$, according to both readers. In 8 cases $(2.4 \%)$ there was concordance on fulfilment of the $\mathrm{mNY}$ criteria. Discordant cases $(n=5,1.4 \%)$ were equally distributed. Agreement between the 2 readers was good with $98.5 \%$ overall agreement and kappa $=0.75$. Therefore, with a more sensitive approach (any of the 2 readers scores $\mathrm{mNY}$ positive) we see slight differences; 13 patients $(3.8 \%)$ fulfil the $\mathrm{mNY}$ criteria. Table 1 shows radiographic damage by individual readers

Table. Baseline data on radiographic damage of the sacroiliac joints in Belgian patients with newly diagnosed or existing PsA included in the BEPAS.

\begin{tabular}{clcccc}
\hline $\mathrm{N}=338$ & \multicolumn{2}{c}{ Right sacroiliac joint } & \multicolumn{2}{c}{ Left sacroiliac joint } \\
\hline Grades & Type of lesion & Reader 1 & Reader 2 & Reader 1 & Reader 2 \\
0 & No abnormalities & $298(88.2 \%)$ & $301(89.1 \%)$ & $298(88.2 \%)$ & $296(87.6 \%)$ \\
1 & Indefinite abnormalities & $32(9.5 \%)$ & $23(6.8 \%)$ & $27(8.0 \%)$ & $23(6.8 \%)$ \\
$2-3$ & Abnormalities & $5(1.5 \%)$ & $12(3.6 \%)$ & $9(2.7 \%)$ & $19(5.6 \%)$ \\
& Erosion & $3(0.9 \%)$ & $11(3.3 \%)$ & $4(1.2 \%)$ & $18(5.3 \%)$ \\
& Sclerosis & $4(1.2 \%)$ & $12(3.6 \%)$ & $5(1.5 \%)$ & $13(3.9 \%)$ \\
& Joint space alteration & $1(0.3 \%)$ & $1(0.3 \%)$ & $4(1.2 \%)$ & $2(0.6 \%)$ \\
& (narrowing or widening) & & & & \\
\multirow{2}{*}{4} & Partial ankylosis & $2(0.6 \%)$ & $3(0.9 \%)$ & $5(1.5 \%)$ & $8(2.4 \%)$ \\
& Total ankylosis & $3(0.9 \%)$ & $2(0.6 \%)$ & $4(1.2 \%)$ & - \\
\hline
\end{tabular}

In 128 patients (37.9\%) a follow-up x-ray after 2 years was available. In 124 patients $(96.9 \%)$ there was reader agreement on $\mathrm{mNY}$ negative status. There was disagreement between readers on a positive $\mathrm{mNY}$ in 2 patients (equally distributed) and agreement on 2 patients (1.6\%). There were no patients with consensus between readers on the change in mNY over 2 years, but 1 reader reported 1 patient becoming $\mathrm{mNY}$ positive after 2 years.
Conclusion: Despite the patient self-identified presence of axial disease in up to $34 \%$ in this cohort of PsA patients, there was minimal radiographic damage on SIJ, suggesting that SIJ disease is not a major manifestation of PSA.

Disclosure of Interests: Manouk de Hooge: None declared, Alla Ishchenko: None declared, Serge Steinfeld: None declared, Adrien Nzeusseu Toukap Grant/research support from: AbbVie, Celgene Corporation, Janssen, Pfizer, UCB - grant/research support, Consultant of: AbbVie, Eli Lilly, Janssen Novartis, UCB - consultant, Speakers bureau: AbbVie, Eli Lilly, Janssen, Novartis, UCB - advisory board member, Dirk Elewaut: None declared, Hermine Leroi Employee of: MSD Belgium, Rik Lories Grant/research support from: AbbVie, Boehringer Ingelheim, Celgene Corporation, Eli Lilly, Galapagos, Janssen, MSD, Novartis, Pfizer, Samumed and UCB - grant/research support (on behalf of Leuven Research and Development), Consultant of: AbbVie, Boehringer Ingelheim, Celgene Corporation, Eli Lilly, Galapagos, Janssen, MSD, Novartis, Pfizer, Samumed and UCB - consultant (on behalf of Leuven Research and Development), Speakers bureau: AbbVie, Boehringer Ingelheim, Celgene Corporation, Eli Lilly, Galapagos, Janssen, MSD, Novartis, Pfizer, Samumed and UCB - speaker (on behalf of Leuven Research and Development), Kurt de Vlam Grant/research support from: Celgene, Eli Lilly, Pfizer Inc, Consultant of: AbbVie, Eli Lilly, Galapagos, Johnson \& Johnson, Novartis, Pfizer Inc, UCB, Filip van den Bosch Consultant of: AbbVie, Celgene Corporation, Eli Lilly, Galapagos, Janssen, Novartis, Pfizer, and UCB, Speakers bureau: AbbVie, Celgene Corporation, Eli Lilly, Galapagos, Janssen, Novartis, Pfizer, and UCB

DOI: 10.1136/annrheumdis-2020-eular.2392

\section{OP0056 PERSISTENCE OF BIOLOGIC TREATMENT IN PSORIATIC ARTHRITIS: A POPULATION-BASED STUDY IN SWEDEN}

K. Geale $^{1,2}$, I. Lindberg ${ }^{1}$, E. Paulsson ${ }^{1}$, C. Wennerström ${ }^{3,4}$, A. Tjärnlund ${ }^{3}$, V. Taliadouros ${ }^{3}$, W. Noel ${ }^{3}$, D. Enkusson ${ }^{3}$, E. Theander ${ }^{3}$, S. Bruce Wirta ${ }^{3}$. ${ }^{1}$ Quantify Research AB, Stockholm, Sweden; ${ }^{2}$ Public Health and Clinical Medicine, Umeå University, Umeå, Sweden; ${ }^{3}$ Janssen Pharmaceutica NV, Sweden, Belgium; ${ }^{4}$ Department of Epidemiology Research, Statens Serum Institut, Copenhagen, Denmark

Background: Psoriatic arthritis (PsA) is a chronic, heterogeneous, immune-mediated seronegative arthritis characterized by joint inflammation in people with skin psoriasis ( $\mathrm{PsO}$ ). In recent years several effective biologic treatments such as tumour necrosis factor inhibitors (TNFi), interleukin (IL) 12 and 23 inhibitors (IL-12/23i), and IL 17 inhibitors (IL-17i) have been introduced for PsA. Discontinuation (non-persistence) of therapy is usually a consequence of lack of effect and intolerability.

Objectives: Compare time to discontinuation of TNFi (adalimumab, ADA), IL-17i (secukinumab, SEC), and IL-12/23i (ustekinumab, UST) treatment exposures and the association with previous biologic treatment experience.

Methods: Population-based national health data from the Swedish Patient Registry, Prescribed Drug Registry and Cause of Death Registry were linked at the patient level and used to identify treatment exposures in PsA patients initiating ADA, SEC, or UST between January 2008 and September 2018. Discontinuation was defined as a treatment switch to any other PsA-indicated biologic, or failure to re-dispense treatment within a grace period following end of drug supplied. The grace period, defined as the number of days between end of drug supply and re-dispensation during which a patient is considered to be on active treatment, was set dynamically to the number of days of drug supplied in the primary analysis. As a sensitivity analysis, a fixed 90-day grace period was used. Supply was calculated as total milligrams dispensed divided by maintenance dose posology, where the following assumptions were made due to the limitations of the administrative data used: UST patients' weight corresponded to the amount of drug dispensed (both $45 \mathrm{mg}$ and $90 \mathrm{mg}$ dispensations last 84 days), SEC patients with prior TNFi experience consumed $300 \mathrm{mg} / 28$ days and all others consumed $150 \mathrm{mg} / 28$ days, and ADA patients consumed $40 \mathrm{mg} / 14$ days. Adjusted hazard ratios (HR) for time to discontinuation were calculated using a Cox proportional hazards model. Covariates for age, marital status, and previous biologic treatment experience were assessed at the initiation of treatment exposure, while comorbidity including skin $\mathrm{PsO}$ was assessed during the two years prior. Exposures without discontinuation events were censored at death or end of follow-up. The study was approved by the Stockholm Regional Ethical Review Board.

Results: 3,620 discontinuation events were observed in the main analysis across 4,649 treatment exposures (ADA: 3,255; SEC: 887; UST: 507) (Figure 1 unadjusted). 3,162 events were observed in the sensitivity analysis. Average age at treatment initiation was $50,54 \%$ were female, $47 \%$ were biologic treatment naïve, and $39 \%$ had skin PsO. In the multivariate main analysis, UST exhibited lower discontinuation rates vs $\mathrm{ADA}(\mathrm{HR}=0.56,95 \% \mathrm{Cl}$ : $0.49-0.64)$ while there 